\title{
DINAMIKA PSIKOLOGIS PEMBUNUH USIA DEWASA: SEBUAH STUDI KASUS
}

\author{
Christina Fieliani Octavia \\ Email: cfoctavia@gmail.com \\ Fakultas Psikologi, Universitas Surabaya
}

\begin{abstract}
Abstrak
Kriminalitas terus terjadi disekitar kita dan dapat mengancam siapa saja. Pembunuhan adalah salah satu perilaku kriminal yang sangat kejam dan juga mampu membuat individu berhadapan dengan hukuman yang sangat berat. Pada kenyataannya, banyak individu memutuskan tetap melakukan pembunuhan. Tujuan penelitian ini adalah mengetahui dinamika psikologis seorang pembunuh usia dewasa. Penelitian ini akan mencoba mengetahui faktor internal dan eksternal yang menyebabkan individu melakukan pembunuhan. Penelitian ini menggunakan metode penelitian kualitatif dengan pendekatan studi kasus (case study). Partisipan dalam penelitian ini berjumlah satu orang, yaitu Danang (bukan nama sebenarnya). Danang terbukti secara sah melakukan pembunuhan dan mendapatkan vonis 7 tahun penjara. Data pada penelitian ini diperoleh melalui wawancara, observasi, dan beberapa tes psikologi. Hasil pemeriksaan menunjukkan faktor internal seperti regulasi emosi yang maladaptif, rendahnya empati, kecenderungan impulsif, dan rendahnya moralitas ataupun norma menyebabkan partisipan melakukan pembunuhan. Faktor eksternal yang berperan seperti pola asuh pengabaian (neglect) dan menjalin relasi dengan orang yang mendukung serta juga melakukan perilaku kriminal. Hasil penelitian ini dapat digunakan sebagai salah satu acuan dalam memberikan intervensi bagi para pelaku pembunuhan ataupun membantu mengurangi terjadinya pembunuhan seperti melalui pelatihan empati ataupun regulasi emosi.
\end{abstract}

Kata Kunci: Dinamika Psikologis, Pembunuhan, Faktor Internal, Faktor Eksternal

Abstract. Crime continues to occur around us and threathens everyone. Murder is a vicious crime that can put the murderer to face severe punishment. However, some individuals still decided to perform this crime. This research was conducted to analyze the psychological dynamics of an adult murderer. In this research, both internal and external factors leading this person to conduct the murder were analyzed. This qualitative research was conducted in the form of case study. The participant of this research was Danang who was legally proven to commit murderer and has been sentenced to 7 years in prison. The data of this research were obtained from interviews, observations and a series of psychological tests. The results of this research showed that internal factors including maladaptive emotion regulation, lack of empathy, impulsive tendency and weak morality and norms led the participant to commit the murder. Meanwhile, external factors including parenting mistakes in the form of neglect and maintaining relationship with people who support the crime also contributed to the action. The results of this research can be used as a valuable insight in determining proper intervention given to murderers and help preventing murder cases through empathy training or emotion regulation training.

Keywords: Psychological Dynamics, Murder, Internal Factor, External Factor

\section{PENDAHULUAN}

Pembunuhan merupakan salah satu tindakan kriminal yang seringkali terjadi disekitar kita. Mabes Polri menyatakan terdapat 625 kasus pembunuhan yang terjadi diseluruh Indonesia mulai bulan Januari hingga Oktober 2018 (Persada, 2018). Pelaku pembunuhan bisa dari segala usia, tidak terkecuali individu dewasa. Ketika melihat lebih jauh mengenai kasus pembunuhan yang terjadi, nampak bahwa kejadian kecil juga dapat memicu individu memutuskan melakukan pembunuhan. Sebagai contoh, seorang laki-laki berusia 22 tahun tega membunuh rekan kerja yang baru dikenalnya. Pelaku menyatakan dirinya merasa kesal karena korban tidak membagi air untuk mandi 
maupun mencuci kepadanya (Wahidin, 2019). Terdapat pula seorang laki-laki berusia 27 tahun yang memutuskan membunuh tetangganya sendiri karena korban mengejek pelaku dengan mengatakan "Hitam Dekil" (Wildansyah, 2019). Dua contoh kasus di atas menunjukkan bahwa individu dapat dengan mudah dan tergolong cepat untuk memutuskan melakukan pembunuhan. Disisi lain, melakukan pembunuhan menempatkan individu pada risiko yang sangat besar dan hukuman yang berat. Berdasarkan kondisi ini, suatu hal yang menarik dan penting untuk mengetahui dinamika psikologis yang melatarbelakangi individu melakukan pembunuhan.

Faktor biologis dan psikologis dinilai berperan dalam individu menunjukkan tindakan kriminal. Faktor biologis seperti genetik, neurotransmitter, dan juga hormon telah diteliti kontribusinya dalam terbentuknya tindakan kriminal (Fox, 2017). Faktor psikologis seperti impulsifitas dan kurangnya empati selama ini juga telah banyak dikaitkan dengan tindakan kriminal.

\section{KAJIAN PUSTAKA}

Pembunuhan didefinisikan sebagai tindakan yang disengaja untuk mengambil atau menghabisi nyawa orang lain.
Pembunuhan dapat dibagi menjadi tiga subkategori. Subkategori pertama merupakan pembunuhan yang berkaitan dengan kegiatan kriminal lainnya seperti kejahatan terorganisir dan perdagangan narkoba. Subkategori kedua adalah pembunuhan interpersonal. Pembunuhan ini terjadi akibat adanya konflik antara seseorang dengan lainnya seperti pembunuhan pasangan intim, anggota keluarga, bahkan pembunuhan yang dilatarbelakangi untuk membalas dendam. Subkategori ketiga adalah pembunuhan sosial-politik, pembunuhan ini memiliki ciri adanya usaha untuk memperlihatkan kekuasaan. Contoh dari pembunuhan sosial-politik adalah pembunuhan karena aksi teror (Hart, 2015).

Tindakan pembunuhan juga dapat dibedakan menggunakan kategori lainnya. Lembaga penegak hukum seringkali mengkategorikan pembunuhan menurut karakteristik pelaku (misalnya geng vs non-geng), korban (misalnya pembunuhan pada anak, kekerasan pada remaja, kekerasan pada individu lanjut usia), berdasarkan konteks situasional (misalnya kekerasan dalam rumah tangga, penyerangan terhadap orang asing, atau pembunuhan di tempat kerja). Motif terjadinya pembunuhan juga beragam termasuk kecemburuan, balas dendam, cinta segita, perampokan, kekerasan 
seksual, ataupun pencurian narkoba (Godwin, 2001).

Sebagai manusia yang sebenarnya dikodratkan untuk hidup saling berdampingan dan tolong menolong, tentunya terdapat berbagai penyebab yang membuat individu sampai bertekad melukai bahkan merenggut nyawa orang lain. Penyebab pertama adalah regulasi emosi yang maladaptif. Regulasi emosi yang maladaptif telah dikaitkan dengan kesehatan mental yang lebih buruk dan peningkatan perilaku bermasalah (Tull et al., 2012). Regulasi emosi sendiri merupakan suatu proses individu memengaruhi emosi yang dirasakannya, bagaimana individu mengalami, dan kemudian mengekspresikan emosi tersebut (Gross, 2002). Terdapat 2 jenis regulasi emosi yang maladaptif yaitu emotional under-regulation dan emotional over-regulation. Emotional underregulation juga berperan dalam memunculkan perilaku agresif karena membuat individu tidak mampu menghambat perilaku impulsif. Emotional over-regulation ditunjukkan dengan menghindari (avoidance) ataupun menekan (suppression) pengalaman emosi yang sedang dirasakan. Strategi ini jika digunakan terus menerus akan membuat individu kesulitan untuk mengetahui informasi yang tepat terkait emosi.
Kondisi ini akhirnya dapat memengaruhi keputusan individu untuk menunjukkan perilaku agresif (Roberton, Daffern, \& Bucks, 2014).

Penyebab lainnya yaitu kurangnya kemampuan untuk berempati terhadap orang lain. Empati merupakan kemampuan individu untuk memahami dan menghargai keadaan emosional serta kebutuhan orang lain. Diaz-Galvan, Ostrosky-shejet, \& Romero-Rebollar (2015) menyatakan bahwa simpati dan empati merupakan faktor yang memotivasi individu melakukan perilaku prososial daripada perilaku antisosial. Empati dinilai berperan penting dalam menghambat terjadinya perilaku agresif (Herpertz \& Sass, 2000). Penyebab lainnya yang seringkali dikaitkan dengan perilaku agresif ataupun tindakan kriminal adalah impulsifitas. Hal ini terjadi karena individu impulsif cenderung cepat bereaksi terhadap suatu hal tanpa memikirkan dampak bagi diri sendiri ataupun orang lain. Sebagai contoh, ketika individu direndahkan oleh temannya terkait penampilan fisiknya, individu impulsif dapat langsung bereaksi menunjukkan kemarahannya. Kemarahan bisa ditunjukkan dengan agresi verbal atau fisik. Impulsifitas sendiri telah dikaitkan dengan terbentuknya perilaku bermasalah dan kriminal seperti seks bebas, 
penggunaan narkoba, agresi, dan kekerasan (Griffin et al dalam Martin et al., 2019).

Teori lain yang dapat digunakan untuk menjelaskan penyebab terjadinya perilaku kriminal adalah social learning theory (SLT). SLT terkait kriminalitas terdiri dari beberapa konsep (Fox, 2017), yaitu: (1) asosiasi diferensial, menyatakan semakin sering individu berhubungan atau menjalin interaksi dengan orang yang terlibat perilaku kriminal, semakin besar kemungkinan orang tersebut juga terlibat dalam perilaku kriminal; (2) definisi, menyatakan individu memiliki kemungkinan besar untuk berperilaku kriminal ketika seringkali berhubungan dengan orang yang memberikan definisi mendukung untuk berperilaku kriminal; (3) penguatan diferensial (differential reinforcement), individu memutuskan melakukan perilaku tertentu tergantung pada keseimbangan imbalan dan hukuman yang akan diterima; (4) imitasi, atau yang biasanya juga disebut sebagai "modeling", yaitu kemungkinan individu meniru perilaku orang lain dipengaruhi oleh karakteristik model, perilaku yang diamati, dan konsekuensi yang didapatkan oleh model. Ketika individu mengamati orang yang dikaguminya melakukan tindakan kriminal dan mendapatkan hasil yang menyenangkan, individu tersebut lebih mungkin untuk meniru dan juga mengadopsi perilaku kriminal tersebut.

Penelitian ini bertujuan untuk mengetahui dinamika psikologis pelaku kriminal khususnya pelaku pembunuhan. Pembunuhan merupakan suatu bentuk agresi fisik yang paling kejam karena bertujuan menghabisi nyawa seseorang bukan hanya sekedar melukai. Penelitian ini diharapkan dapat menyumbangkan informasi ataupun data lapangan pada pengembangan ilmu psikologi forensik. Selain itu, penelitian ini diharapkan bisa menjadi salah satu referensi data untuk peneliti lainnya dalam membuat profiling seorang pembunuh dan juga menjadi acuan merancang intervensi bagi pelaku pembunuhan ataupun kriminal.

\section{METODE PENELITIAN}

Penelitian ini menggunakan metode penelitian kualitatif dengan pendekatan studi kasus (case study). Menurut Merriam (dalam Yazan, 2015) studi kasus kualitatif adalah suatu deskripsi mendalam dan menyeluruh tentang suatu fenomena yang memiliki batasan seperti program, lembaga, orang, proses, ataupun unit sosial. Yin (2002) menyampaikan bahwa studi kasus adalah penyelidikan empiris terkait suatu kasus atau menjawab pertanyaan "bagaimana" atau "mengapa" tentang suatu fenomena. Penelitian ini secara khusus ingin mendalami kasus 
individu yang melakukan pembunuhan untuk dapat mengetahui dinamika psikologisnya.

Partisipan dalam penelitian ini merupakan seorang narapidana berjenis kelamin laki-laki dan berusia 27 tahun. Narapidana ini terjerat pasal 340 KUHP dan harus menjalani masa hukuman selama 7 tahun di Lembaga Pemasyarakatan Jawa Timur. Partisipan melakukan pembunuhan pada tahun 2016, tepatnya saat partisipan berusia 25 tahun. Pendidikan terakhir partisipan adalah SMP dan sebelum terjerat kasus pembunuhan, partisipan sempat bekerja sebagai tukang kebun dan kemudian berganti pekerjaan menjadi kuli bangunan

Teknik pengumpulan data dalam penelitian ini menggunakan wawancara, observasi, dan tes psikologi. Tes psikologi

\section{HASIL DAN PEMBAHASAN}

Partisipan melakukan pembunuhan terhadap seseorang yang dinilai sebagai "orang ketiga" dalam jalinan asmaranya. Orang ketiga yang kemudian menjadi korban dinilai sudah mengganggu hubungan partisipan dengan pacarnya. Partisipan sudah melaksanakan tunangan bersama pacarnya, namun kehadiran korban akhirnya membuat pacar partisipan membatalkan pertunangan yang sudah dilaksanakan termasuk juga memutuskan yang diberikan berupa tes kecerdasan, proyektif, dan inventori. Tes kecerdasan menggunakan Wechsler Bellevue Intelligence (WB). Tes proyektif menggunakan Drawing Completion Test (DCT), BAUM, House Tree Person (HTP), Draw A Person (DAP), Thematic Apperception Test (TAT), dan Sacks Sentence Completion Test (SSCT). Tes inventori menggunakan HARE SelfReport yang bertujuan untuk mengetahui kecenderungan psikopatik pada individu. Pada proses asesmen atau pemeriksaan, wawancara dilakukan berulang-ulang kali untuk menguji konsistensi jawabanjawaban yang diberikan oleh partisipan. Selain itu, peneliti juga menggunakan data wawancara, observasi, maupun tes psikologi dalam menginterpretasi ataupun menyimpulkan sesuatu

hubungan mereka. Korban seringkali menjelek-jelekkan partisipan di depan pacarnya seperti menyampaikan bahwa partisipan kembali mengonsumsi narkoba, alkohol, dan sering pergi ke tempat lokalisasi. Partisipan menyatakan bahwa hal yang dituduhkan korban terhadapnya tidak benar.

Berikut ini adalah rekapitulasi hasil asesmen yang telah dilakukan, yaitu: 
Tabel 1. Rekapitulasi Hasil Asesmen

\begin{tabular}{|c|c|}
\hline Butir-butir Temuan Asesmen & Sumber Data \\
\hline \multicolumn{2}{|l|}{ Kemampuan intelektual/kognitif } \\
\hline $\begin{array}{l}\text { Partisipan memiliki kemampuan intelektual yang tergolong rata- } \\
\text { rata, hal ini menunjukkan bahwa partisipan cukup mampu untuk } \\
\text { menerima dan mencerna berbagai informasi yang diperoleh dari } \\
\text { luar. Memiliki kemampuan intelektual yang rata-rata juga } \\
\text { memperluas kesempatan partisipan untuk bisa bekerja diberbagai } \\
\text { bidang, namun partisipan nampak lebih berminat pada bidang } \\
\text { pekerjaan yang bersifat praktikal. }\end{array}$ & $\begin{array}{l}\text { - WB } \\
\text { - Wawancara } \\
\text { - Observasi }\end{array}$ \\
\hline \multicolumn{2}{|l|}{ Kontrol dan dorongan } \\
\hline $\begin{array}{l}\text { Partisipan memiliki dorongan agresi yang tidak begitu besar, } \\
\text { namun ketika dalam kondisi tertekan dan terus menerus disakiti, } \\
\text { dorongan ini akan dimunculkan keluar bahkan tanpa } \\
\text { menggunakan dasar pemikiran yang matang. Partisipan juga } \\
\text { tidak mampu mengontrol dorongan-dorongan yang ada dalam } \\
\text { dirinya karena tidak memiliki norma dan juga impulsif, sehingga } \\
\text { partisipan akan melakukan segala cara termasuk cara-cara yang } \\
\text { melanggar norma atau aturan sosial demi mendapatkan yang } \\
\text { diinginkannya. }\end{array}$ & $\begin{array}{l}\text { - WB } \\
\text { - BAUM } \\
\text { - DAP } \\
\text { - TAT } \\
\text { - HARE } \\
\text { - Wawancara }\end{array}$ \\
\hline \multicolumn{2}{|l|}{ Emosi dan Afeksi } \\
\hline $\begin{array}{l}\text { Partisipan merupakan individu yang lebih banyak dipengaruhi } \\
\text { oleh emosi dibandingkan rasio ketika bertindak. Hal ini membuat } \\
\text { partisipan terkadang dapat dengan mudah berperilaku impulsif } \\
\text { seperti terlibat dalam perilaku yang merugikan orang lain. Disisi } \\
\text { lain, partisipan seringkali juga berusaha untuk tidak } \\
\text { mengekspresikan emosi yang dirasakannya melainkan cenderung } \\
\text { menekannya ataupun memendamnya. Kedua kondisi ini } \\
\text { sebenarnya menunjukkan bahwa partisipan kurang mampu } \\
\text { mengelola atau meregulasi emosinya dengan tepat. Ketika dalam } \\
\text { relasi sosial, partisipan kurang mampu melibatkan emosi positif, } \\
\text { sehingga membuatnya kesulitan menunjukkan empati kepada } \\
\text { orang lain. }\end{array}$ & $\begin{array}{l}\text { - DAP } \\
\text { - DCT } \\
\text { - BAUM } \\
\text { - HARE } \\
\text { - Wawancara }\end{array}$ \\
\hline \multicolumn{2}{|l|}{ Penyesuaian dalam Hubungan Interpersonal } \\
\hline $\begin{array}{l}\text { Partisipan tampak kurang mendapatkan dukungan dan kasih } \\
\text { sayang di dalam keluarganya. Hal ini membuatnya berusaha } \\
\text { mencari pemenuhan kebutuhan tersebut di luar keluarga, } \\
\text { sehingga partisipan cukup memiliki minat dalam menjalin relasi } \\
\text { sosial meskipun ia tidak sepenuhnya percaya diri ketika menjalin } \\
\text { relasi. Hal ini akhirnya membuat partisipan berusaha untuk } \\
\text { memanipulasi orang disekitarnya agar dirinya dapat akrab dan } \\
\text { diterima. Ketika terjadi suatu perselisahan atau dirinya disakiti, } \\
\text { partisipan adalah individu yang terus mengingat hal-hal tersebut } \\
\text { dan di dalam diri partisipan kurang ada rasa empati. Dua kondisi }\end{array}$ & $\begin{array}{l}\text { - WB } \\
\text { - DCT } \\
\text { - BAUM } \\
\text { - DAP } \\
\text { - SSCT } \\
\text { - TAT } \\
\text { - HARE } \\
\text { - HTP } \\
\text { - Wawancara } \\
\text { - Observasi }\end{array}$ \\
\hline
\end{tabular}


ini membuat partisipan berpotensi melakukan tindakan yang merugikan termasuk tindakan yang melukai orang lain.

\section{Konflik dan Cara Penyelesaian Masalah}

Konflik yang sering terjadi dalam diri partisipan adalah adanya - DCT

keinginan untuk menjalin relasi yang akrab dengan orang lain - TAT

dan juga ingin dipandang sebagai individu yang baik, namun - HARE

disisi lain partisipan juga memendam atau menyimpan berbagai - Wawancara

kekesalan dan kemarahan terhadap orang-orang terdekatnya.

Kekesalan dan kemarahan ini dicoba untuk terus ditekan dan juga tidak diselesaikan, hingga ketika partisipan terus menerus disudutkan dan disakiti, ia akan membalas menyakiti dengan berperilaku agresif. Hal ini dapat terjadi karena dalam menyelesaikan masalah khususnya masalah yang bersifat emosional, partisipan akan lebih mengutamakan emosinya dibandingkan rasio.

Pemeriksaan atau asesmen yang telah dilakukan menunjukkan hasil bahwa tindakan pembunuhan yang dilakukan oleh partisipan disebabkan oleh beberapa faktor internal dan faktor eksternal. Faktor internal pertama yaitu kurangnya kemampuan partisipan untuk mengelola emosinya dengan adaptif atau tepat. Selama ini, partisipan lebih banyak menekan emosi yang dirasakan atau berusaha untuk tidak merasakan pengalaman emosi yang sebenarnya. Sebagai contoh, ketika kakak laki-laki pertisipan memarahi partisipan karena seringkali pulang larut malam bahkan pagi hari, partisipan menyatakan dirinya merasa kesal, namun pertisipan berusaha keras untuk tidak menunjukkan kekesalannya tersebut. Partisipan memilih untuk hanya diam sambil mendengarkan kakaknya berbicara. Peristiwa ini terus berulang hingga akhirnya terjadi pertengkaran diantara partisipan dan kakak laki-lakinya. Partisipan menyatakan pertengkaran terjadi karena dirinya sudah tidak sanggup menahan kekesalan kepada kakaknya. Terkait dengan kemarahan partisipan terhadap korban, partisipan juga terus berusaha untuk menekannya. Partisipan menyatakan dirinya tidak secara langsung menemui korban untuk mengajak berbicara dan menyampaikan yang dirasakannya saat pacar partisipan mulai mempermasalahkan yang disampaikan korban. Kondisi ini terus berulang hingga puncaknya saat pacar partisipan membatalkan pertunangan mereka sekaligus mengakhiri hubungan mereka, partisipan tidak mampu lagi menahan kemarahannya kepada korban hingga nekat melakukan pembunuhan. 
Strategi pengelolaan emosi yang digunakan oleh partisipan tergolong suppression. Suppression dinyatakan sebagai pengelolaan emosi yang maladaptif dan juga telah dikaitkan dengan terbentuknya perilaku agresif. Gross \& Levenson (1997) menyatakan bahwa ketika individu berusaha untuk menekan emosi yang dirasakannya (suppression), individu tersebut akan kurang menunjukkan ekspresi dari emosi negatif yang dirasakan, namun disisi lain emosi negatif yang dialami secara fisiologis meningkat. Hal ini terjadi dikarenakan saat individu berusaha menekan emosi negatifnya, emosi positif ikut ditekan, sehingga individu juga merasakan emosi positif yang rendah. Roberton, Daffern, \& Bucks (2014) menyatakan terdapat dua gaya pengelolaan emosi maladaptif yaitu under-regulation dan over-regulation. Suppression tergolong dalam overregulation. Melakukan suppression dinyatakan telah terbukti meningkatkan pengaruh negatif (Gratz \& Roemer, 2004), karena menimbulkan ketidaknyamanan yang lebih di dalam diri individu. Alasan lainnya, suppression mengakibatkan terkurasnya sumber daya kognitif seperti memori dan fokus pada tugas maupun pekerjaan tertentu. Terkurasnya sumber kognitif ini dapat membuat individu kesulitan untuk berpikir dengan akal sehat dan mendalam, sehingga memengaruhi keputusannya untuk menyerang atau menunjukkan perilaku agresif (Gross, 2002).

Partisipan akan memunculkan perilaku agresif ketika dirinya terus tertekan dan tersakiti bahkan sampai membunuh juga dikarenakan partisipan cenderung impulsif. Kondisi ini membuat partisipan kurang mampu memikirkan dampak bagi dirinya maupun korban ketika melakukan pembunuhan. Perilaku impulsif dinyatakan dapat mengakibatkan kerusakan bagi diri sendiri atau dapat pula ditunjukkan sebagai kekerasan terhadap orang lain (Coccaro, 2015). Penelitian yang dilakukan oleh Li, Commons, Duong, \& Going (2019) menemukan bahwa individu yang impulsif dan juga kurang mampu membangun hubungan yang lekat dengan orang lain, cenderung melakukan kejahatan yang tergolong paling parah. Kecenderungan impulsif tidak terlepas dari pengelolaan emosi yang maladaptif dalam diri partisipan. Pengelolaan emosi yang maladaptif salah satunya ditunjukkan melalui emotional under-regulation. Emotional underregulation membuat individu tidak mampu menghambat perilaku impulsif. Hal ini dapat terjadi karena individu hanya terfokus pada kemarahan yang muncul 
dalam dirinya, sehingga membuatnya tidak mampu berpikir secara mendalam dan berulang yang akhirnya memengaruhi keputusannya untuk berperilaku agresif (Roberton, Daffern, \& Bucks, 2014).

Faktor ketiga yang dinilai juga berperan menyebabkan partisipan melakukan tindakan pembunuhan adalah kurang mampu berempati. Hasil wawancara menunjukkan bahwa partisipan sering melakukan pencurian bahkan partisipan pernah membakar sawah dan tanaman milik orang lain karena dirinya merasa kesal dengan pemilik sawah tersebut. Sampai saat ini partisipan mengaku bahwa dirinya tidak pernah terpikirkan atau merasa kasihan kepada korban pencurian, penipuan, dan juga korban yang sawahnya dibakar olehnya. Partisipan juga mengatakan bahwa ia tidak memiliki rasa bersalah atau penyesalan kepada korban yang telah ia bunuh, karena partisipan merasa sangat yakin korban pantas mendapatkan perlakuan tersebut. Hal ini juga didukung oleh hasil tes HARE partisipan, diketahui partisipan memperoleh skor tinggi pada aspek lack of empathy. Pemeriksa kemudian mengajukan pertanyaan kepada partsipan terkait emosi yang dapat dirasakan oleh korban pencurian maupun korban yang sawahnya dibakar olehnya. Partisipan sempat terdiam sejenak, kemudian menjawab bahwa para korban tersebut mungkin merasa marah. Terkait dengan korban pembunuhan, partisipan menyatakan bahwa keluarganya kemungkinan besar merasakan kesedihan.

Miller \& Eisenberg (dalam Marshall \& Marshall, 2011) menyatakan bahwa empati mendasari munculnya perilaku menolong orang lain dan tidak adanya empati menghasilkan perilaku agresif yang mengabaikan hak ataupun penderitaan orang lain. Marshall \& Marshall (2011) merumuskan 4 tahapan atau proses dalam empati, yaitu: (1) pengakuan terkait emosi yang dirasakan orang lain; (2) mampu melihat sesuatu dari perspektif orang lain atau mampu memposisikan diri pada posisi orang lain; (3) adanya respon emosional atau belas kasih; dan (4) menunjukkan perilaku yang bertujuan untuk mengurangi kesusahan atau tekanan yang dialami orang lain. Ketika melihat lebih dalam terkait ketidakmampuan partisipan menunjukkan empati, nampak jelas bahwa partisipan tidak mampu menunjukkan belas kasih kepada korban (tahap ketiga). Hal ini terjadi dapat dikarenakan partisipan tidak mampu untuk memposisikan dirinya pada posisi orang lain (tahap kedua) seperti memikirkan kerugian yang didapatkan korban pencurian maupun korban yang sawahnya dibakar olehnya. Partisipan juga 
tidak mampu memposisikan dirinya pada posisi keluarga korban yang ia bunuh. Partisipan hanya mampu mencapai tahap satu yaitu mengenali emosi para korban.

Faktor eksternal yang juga berperan pada terbentuknya perilaku kriminal partisipan adalah pola asuh keluarga. Hasil pemeriksaan menunjukkan bahwa partisipan tumbuh dalam keluarga yang kurang memberikan batasan ataupun kontrol terhadap anak, dengan kata lain orantua partisipan cenderung memiliki pola pengasuhan pengabaian atau neglect. Ayah partisipan bekerja di luar kota dari partisipan kecil, hanya pulang ke rumah setiap akhir pekan. Saat pulang ke rumah, ayah partisipan jarang menghabiskan waktu bersama keluarga melainkan lebih memilih untuk pergi memancing. Partisipan juga tidak memiliki hubungan yang dekat dengan ibunya. Ibu partisipan jarang sekali mengajak partisipan untuk berdikusi atau bertanya terkait diri partisipan. Partisipan bahkan menyatakan ibunya tidak mengetahui bahwa partisipan seringkali membolos. Ibu partisipan terkadang saja mengomel atau memarahi partisipan pada hal-hal yang kurang penting seperti malas mandi, namun tidak menaruh perhatian yang besar untuk memberikan pemahaman yang benar terkait moral ataupun norma. Pada akhirnya di dalam diri partisipan tidak tertanam kuat terkait moral dan normanorma sosial (faktor internal keempat). Kurangnya komunikasi antara orangtua dengan anak termasuk membicarakan terkait moralitas, serta kurangnya keterlibatan orangtua dalam hidup anak membuat anak lebih berisiko menunjukkan perilaku bermasalah (Johnson, 2016), termasuk kriminalitas.

Tumbuh dalam keluarga yang cenderung mengabaikan dan kurang memberikan perhatian serta kasih sayang membuat partisipan banyak menghabiskan waktu di luar rumah untuk memenuhi kebutuhan afeksinya. Kondisi ini juga membuat partisipan mempelajari terkait norma dari teman-temannya. Partisipan banyak menghabiskan waktu bersama teman-temannya yang suka berjudi, mabuk-mabukkan, dan juga mengonsumsi narkoba. Tidak hanya itu, teman-teman partisipan bahkan teman-teman sejak SD suka bertengkar dan teman-teman SMP partisipan seringkali bertengkar menggunakan benda tajam. Memasuki masa SMA, partisipan juga menyatakan bahwa teman-temannya seringkali bertengkar hingga adu fisik yang secara garis besar disebabkan oleh masalah wanita. Berbagai kondisi ini menunjukkan bahwa sejak partisipan kecil, ia sudah mengamati bahwa orang-orang disekitarnya menyelesaikan masalah 
menggunakan kekerasan. Kondisi ini tentunya juga berperan dalam membentuk pandangan partisipan dalam menyelesaikan masalah, ditambah lagi kurangnya penanaman yang kuat dalam diri partisipan terkait moral dan norma.

Teori yang dapat digunakan untuk menjelaskan pengaruh orang sekitar terhadap pembentukan perilaku kriminal adalah social learning theory (SLT). Konsep pertama SLT adalah terkait asosiasi diferensial. Konsep ini menyatakan semakin sering individu berhubungan atau menjalin interaksi dengan orang yang terlibat perilaku kriminal, maka semakin besar kemungkinan orang tersebut juga akan terlibat dalam perilaku kriminal. Konsep kedua dari SLT adalah definisi, yaitu mengacu pada sikap dan makna yang dilekatkan individu pada perilaku tertentu. Melalui jalinan relasi sosial, individu belajar terkait definisi dari suatu perilaku sebagai benar atau salah, bermoral atau tidak bermoral. Disisi lain, masih memungkinkan untuk individu berperilaku kriminal atau menyimpang ketika berhubungan dengan orang yang memberikan definisi mendukung terhadap perilaku kriminal (Akers \& Sellers dalam Fox, 2017). Sejak SD partisipan sudah menjalin relasi dengan individu yang suka berkelahi hingga dewasa. Kondisi ini menunjukkan teman-teman partisipan memberikan definisi atau pengertian bahwa melakukan perkelahian bahkan menggunakan benda tajam yang dapat mengancam nyawa orang lain, merupakan suatu hal yang tidak masalah untuk dilakukan.

\section{PENUTUP}

Tindakan pembunuhan yang dilakukan partisipan disebabkan oleh interaksi faktor internal dan eksternal. Regulasi atau pengelolaan emosi yang maladaptif ditemukan menjadi salah satu faktor internal yang berperan membuat partisipan melakukan tindakan kriminal khususnya pembunuhan. Strategi pengelolaan emosi yang digunakan partisipan adalah supression. Suppression dilakukan partisipan sebagai upaya untuk menekan emosi negatif yang dirasakan, namun sebaliknya justru meningkatkan kemarahan dalam diri partisipan. Kondisi ini kemudian membangkitkan keadaan internal permusuhan dan akhirnya mengurangi usaha pencegahan perilaku agresif (Scott, DiLillo, Maldonado, \& Watkins, 2015). Suppression telah dikaitkan terhadap munculnya perilaku agresif (Scott, DiLillo, Maldonado, \& Watkins, 2015; Tull, Jakupcak, Paulson, \& Gratz, 2007).

\section{Emotional}

under-regulation tergolong pada pengelolaan emosi yang 
maladaptif yang juga dapat memunculkan perilaku agresif karena tidak mampu menghambat perilaku impulsif (Roberton, Daffern, \& Bucks, 2014). Faktor internal kedua yang berperan yaitu impulsif. Partisipan kurang mampu berpikir panjang termasuk memikirkan dampak bagi dirinya sendiri maupun orang lain. Kondisi ini membuat partisipan cenderung langsung bertindak berdasarkan dorongan yang dimilikinya. Penelitian yang dilakukan oleh Hatfield \& Dula (2014) menyatakan impulsifitas yang tinggi terkait dengan agresi fisik yang juga lebih tinggi. Faktor internal ketiga yaitu kurang mampu berempati. Miller \& Eisenberg (dalam Marshall \& Marshall, 2011) menyatakan bahwa tidak adanya empati menghasilkan perilaku agresif yang mengabaikan hak ataupun penderitaan orang lain.

Hasil menunjukkan bahwa gaya pengasuhan pengabaian (neglect) dan teman sebaya (faktor eksternal) turut berperan dalam membentuk partisipan melakukan tindakan kriminal. Kurang terjalinnya komunikasi antara orangtua dan anak terkait moralitas, membuat anak berisiko lebih tinggi menunjukkan perilaku bermasalah termasuk kriminalitas. Partisipan nampak belajar terkait moralitas maupun norma dari kelompok ataupun teman sebayanya.
Sejak kecil, partisipan mempelajari dari teman-temannya bahwa masalah diselesaikan menggunakan kekerasan. Partisipan juga berteman dengan orangorang yang seringkali bertengkar dan mencuri. Hal ini sejalan dengan pandangan Social Learning Theory (SLT) of Crime bahwa individu yang seringkali menjalin interaksi dengan orang yang terlibat perilaku kriminal dan juga memberikan definisi mendukung terkait perilaku kriminal, besar kemungkinannya juga terlibat dalam perilaku kriminal (Fox, 2017).

Satu hal yang cukup menarik dari kasus ini adalah motif partisipan melakukan pembunuhan. Partisipan mengaku melakukan pembunuhan karena masalah asmara. Kondisi ini dapat ditinjau dari teori perkembangan yang dikemukakan oleh Erikson. Partisipan saat melakukan pembunuhan berusia 24 tahun dan berada pada tahapan intimacy $v s$ isolation. Erikson mendeskripsikan keintiman adalah sebuah proses menemukan diri sendiri sekaligus penyatuan diri sendiri dengan orang lain. Ketika individu gagal mengembangkan relasi yang intim dimasa ini dengan lawan jenis, individu tersebut akan mengalami isolasi. Ketidakmampuan untuk mengembangkan relasi yang bermakna dapat menggiring individu untuk tidak 
mau mengakui, mengabaikan, atau bahkan menyerang orang-orang yang dinilai menimbulkan frustasi (Santrock, 2012). Partisipan sampai melakukan pembunuhan yang disebabkan oleh masalah asmara dapat dikarenakan karena partisipan sedang berada dalam tahap yang mengutamakan hubungan interpersonal mendalam dengan lawan jenis.

Saran bagi penelitian selanjutnya adalah melakukan analisis dinamika psikologis bagi wanita yang melakukan tindakan kriminal. Hal ini dilakukan agar memperoleh tambahan pengetahuan mengenai pengaruh jenis kelamin terhadap tindakan kriminal. Penelitian selanjutnya juga dapat merancang dan memberikan intervensi sesuai dengan permasalahan yang ditemukan pada pelaku kriminal seperti strategi regulasi emosi yang adaptif, self-control untuk mengatasi impulsif, dan pelatihan terkait empati. Selain itu, agar memperolah data yang lebih lengkap, penelitian selanjutnya dapat menggunakan self-report quetionnare seeprti untuk mengetahui tingkat impulsifitas partisipan, dan lainlain.

\section{DAFTAR PUSTAKA}

Burgess, R. L., \& Akers, R. L. (1966). A differential associationreinforcement theory of criminal behavior. Social Problems,14, 363383.

Coccaro, E. F. (2015). The nature of impulsive aggression: Commentary on "Aggression in borderline personality disorder-A multidimensional model".

Díaz-Galván, K.X., Ostrosky-Shejet, F., \& Romero-Rebollar, C. (2015). Cognitive and affective empathy: The role in violent behavior and psychopathy. Revista Medica Hosp Gen Méx, 78(1), 27-35.

Fox, B. (2017). It's nature and nurture: Integrating biology and genetics into the social learning theory of criminal behavior. Journal of Criminal Justice, 49, 22-31.

Gratz, K. L., \& Roemer, L. (2004). Multidimensional assessment of emotion regulation and dysregulation: Development, factor structure, and initial validation of the difficulties in emotion regulation scale. Journal of Psychopathology and Behavioral Assessment, 26(1), 41-54.

Gross, J. J., \& Levenson, R.W. (1997). Hiding feelings: The acute effects of inhibiting negative and positive emotion. Journal of Abnormal Psychology, 106, 95-103.

Gross, J. J. (2002). Emotion regulation: Affective, cognitive, and social consequences. Psychophysiology, 39, 281-291.

Godwin, G.M. (2001). Criminal psychology and forensic technology: A collaborative approach to effective profiling. New York: CRC Press.

Hart, R. (2015). An Analysis of Global Homicide Patterns. Tesis. Berkeley: University of California. 
Hatfield, J., \& Dula, C.S. (2014). Impulsivity and Physical Aggression: Examining the Moderating Role of Anxiety. American Journal of Psychology, 127(2), 233-243.

Herpertz, S.C., \& Sass, H. (2000). Emotional Deficiency and Psychopathy. Behavioral Sciences and the Law, 18, 567-580.

Johnson, S.A. (2016). Parenting Styles and Raising Delinquent Children: Responsibility of Parents in Encouraging Violent Behavior. Forensic Research \& Criminology International Journal, 3(1), 1-6.

Li, G., Commons, M.L., Duong, T.Q., \& Going, E.F. (2019). Predicting criminality with social perspective taking, attachment relationship, anger, impulsivity and depression. Ethics, Medicine and Public Health, 8, 146-155.

Marshall, L.E., \& Marshall, W.L. (2011). Empathy and antisocial behaviour. The Journal of Forensic Psychiatry \& Psychology, 22(5), 742-759.

Martin, S., Zabala, C., Del-Monte, J., Graziani, P., Aizpurua, E., Barry, T.J., \& Ricarte, J. (2019). Examining the relationships between impulsivity, aggression, and recidivism for prisoners with antisocial personality disorder. Aggression and Violent Behavior, 18.

Persada, S. (2018). Mabes Polri Sebut Ada 625 Kasus Pembunuhan Sepanjang 2018. Diakses 11 November 2019. Available from https://nasional.tempo.co/read/1275 031/jokowi-resmi-umumkan-7-stafkhusus-milenial-ada-putri-tanjung.
Roberton, T., Daffern, M., \& Bucks, R.S. (2014). Maladaptive emotion regulation and aggression in adult offenders. Psychology, Crime \& Law, 20(10), 933-954.

Santrock, J.W. (2012). Perkembangan Masa Hidup (13 ${ }^{\text {th }}$ ed.) (B. Widyasinta, Pengalih bhs.). Jakarta: Erlangga.

Scott, J. P., DiLillo, D., Maldonado, R. C., \& Watkins, L. E. (2015). Negative urgency and emotion regulation strategy use: Associations with displaced aggression. Aggressive Behavior,41(5), 502-512.

Tull, M. T., Jakupcak, M., Paulson, A., \& Gratz, K. L. (2007). The role of emotional inexpressivity and experiential avoidance in the relationship between posttraumatic stress disorder symptom severity and aggressive behavior among men exposed to interpersonal violence. Anxiety, Stress, \& Coping, 20, 337351.

Tull, M. T., Weiss, N. H., Adams, C. E., \& Gratz, K. L. (2012). The contribution of emotion regulation difficulties to risky sexual behavior within a sample of patients in residential substance abuse treatment. Addictive Behaviors, 37, 1084-1092.

Wahidin. (2019). Hanya Karena Masalah Sepele, Tersangka Tega Habisi Nyawa Purwanto Saat Tidur. Diakses 12 November 2019. Available from https://pontianak.tribunnews.com/20 19/06/21/hanya-karena-masalahsepele-tersangka-tega-habisi-nyawapurwanto-saat-tidur. 
Wildansyah, S. (2019). Dendam Diejek 'Hitam Dekil', Pembunuhan Wanita di Cakung Direncanakan Pelaku. Diakses 12 November 2019. Available from https://news.detik.com/berita/d4780261/dendam-diejek-hitamdekil-pembunuhan-wanita-dicakung-direncanakanpelaku?_ga=2.205184661.46950893 7.15738719712112267970.1573871971 .

Yazan, B. (2015). Three Approaches to Case Study Methods in Education: Yin, Merriam, and Stake.The Qualitative Report, 20(2),134-152.

Yin, R. K. (2002). Case study research: Design and methods. Thousand Oaks, CA: SAGE Publications. 